Воронкова О.С., Вінніков А.І., Щербиніна М.Б., Дикленко Т.В.

\title{
Аналіз ефективності різних схем корекції дисбіозу репродуктивного тракту
}

\author{
Дніпровський національний університет імені Олеся Гончара, м. Дніпро, Україна
}

voronkova.olga.04@gmail.com, a_vinnikov@ukr.net, scherbinina@ua.fm,tdiklenko@gmail.com

\author{
Воронкова О.С., Винников А.И., \\ Щербинина М.Б., Дикленко Т.В. \\ Анализ эффективности различных схем \\ коррекции дисбиоза репродуктивного тракта \\ Днепровский национальный университет \\ имени Олеся Гончара, г. Днепр, Украина
}

\author{
Voronkova O.S., Vinnikov A.I., \\ Shcherbynina M.B., DyklenkoT.V. \\ Analysis of the efficiency of different scheme \\ for the correction of dysbiosis of the reproductive tract \\ Oles Honchar Dnipro National University, \\ Dnipro, Ukraine
}

\section{Вступ}

Серед великого різноманіття патологічних процесів людини особливе місце займають інфекції, викликані стафілококами. Бактерії роду Staphylococcus включають різноманітну групу коменсалів, які колонізують шкіру та слизові оболонки ссавців, у тому числі і людини [21]. Деякі з найбільш відомих представників цього роду, такі як Staphylococcus aureus i Staphylococcus epidermidis, також є опортуністичними патогенами, з якими пов'язано величезне навантаження на систему охорони здоров'я $[23,30]$.

Однією з причин «проблемності» стафілококів є їх здатність прикріплюватися до поверхонь і розвиватися у комплексні структури, відомі як біоплівка $[1,26]$. Проблема стафілококових біоплівок на сьогодні є однією 3 найбільш важливих у медичній практиці, що пов'язано 3 тим, що у біоплівковій формі ці бактерії набувають одночасного посилення властивих їм якостей i нових ознак, особливо якщо мова йде про включення у полімікробні спільноти, існуючі на різних біотопах макроорганізму [21,24]. Стафілококи, зокрема, викликають велику кількість інфекцій, пов'язаних 3 біоплівками, і є вагомим тягарем для системи охорони здоров'я [31]. Зокрема, статистика по США свідчить, що $S$. aureus i коагулазонегативні стафілококи посідають перше i третє місця серед найбільш поширених етіологічних агентів госпітальних інфекцій відповідно, включаючи інфекції, пов'язані з медичним обладнанням і хірургічними ранами [32].

Серед значної кількості даних про моделювання біоплівок зустрічаються лише окремі матеріали про біоплівки, пов'язані з мікробіотою відкритих порожнин організму людини і тварин [29]. Це, зокрема, стосується і моделювання порушень мікробіоти статевих шляхів, хоча відомо, що саме біоплівкова організація на цьому біотопі становить головну загрозу хронізації таких патологічних процесів як бактеріальний вагіноз, адже сприяє затримці транзиторних мікроорганізмів і підвищенню їх виживаності в умовах антагонізму та дії несприятливих факторів оточення [10,21].

У випадку патологічного процесу, пов'язаного 3 біоплівкотвірними мікроорганізмами, відновлення мікробіоти є обов'язковою необхідністю, для чого можуть бути використані різні препарати. Найбільш часто 3 лікувальною метою при інфекційних процесах використовують антибіотики, а при дисбіозах використовують бактеріотерапевтичні препарати пробіотики. Це препарати, що містять живі клітини мікроорганізмів або/та продукти їх метаболізма, що сприятливо впливають на організм людини шляхом оздоровлення іiі мікрофлори [22]. Крім того, у випадках множинної резистентності штамів-збудників виникає потреба у пошуку додаткових терапевтичних засобів, перспективними серед яких вважаються бактеріофаги $[25,28]$.

Метою роботи було проаналізувати ефективність різних схем корекції експериментального дисбіозу репродуктивного тракту, змодельованого шляхом інтравагінального введення біоплівкотвірного штама S. aureus 48 .

\section{Матеріали та методи}

Дослідження 3 моделювання дисбактеріозу піхви проводили на білих лабораторних мишах 3 віварію Дніпровського національного університету імені Олеся Гончара. Відбирали самиць віком 18-24 тижні та вагою 18-22 г, яких утримували в умовах, що відповідають стандарту [7]. Тварин розподіляли на групи випадковим чином у залежності від потреб експерименту. Для дослідження були використані групи тварин, початкова чисельність яких налічувала 10 та більше особин. Детальна характеристика кожної групи наведена у відповідних розділах. 
Кількість мікроорганізмів, виділених 3 піхви тварин, визначали у спосіб, аналогічний до такого, що використовують для аналізу біологічного матеріалу від жінок, відповідно до матеріалів наказу МОЗ України «Про затвердження клінічних протоколів 3 акушерської та гінекологічної допомоги» № 582 від 15.12 .2003 р. [18] та виражали їх у вигляді $\lg (\mathrm{M} \pm \mathrm{m})$.

Для створення дисбактеріозу дослідним тваринам інтравагінально вводили суспензії добових культур біоплівкотвірних та небіоплівкотвірних штамів стафілококів. Суспензії містили $1 \times 10^{9} \quad$ КУО/мл та вводилися по 50 мкл одноразово. Контрольний висів для встановлення відповідності складу мікробіоти ознакам дисбактеріозу виконували через 10 діб, визначаючи зміни складу мікробіоти аналогічно до схеми, запропонованої для існуючої моделі дисбактеріозу репродуктивного тракту мишей [4].

Визначали наявність і кількісне співвідношення аеробних та анаеробних мікроорганізмів згідно наказу MO3 України «Про затвердження клінічних протоколів 3 акушерської та гінекологічної допомоги» № 582 від 15.12.2003 p. [18], а також якісний та кількісний склад мікроорганізмів у відповідності до ознак, що наведені в “Определителе бактерий Берджи” [9], згідно до “Приказа MO3 СССР № 535 «Об унификации микробиологических (бактериологических) методов исследования, применяемых в клинико-диагностических лабораториях лечебно-профилактических учреждений» від 22.04.1985 p. [16] та у відповідності до методичних рекомендацій 3 лабораторної діагностики гнійно-запальних захворювань, зумовлених аспорогенними анаеробними мікроорганізмами [5].

Для корекції дисбактеріозу використовували різні схеми, що включали окремі препарати та їх комплекси: комплекс «Кліндаміцин» - «Вагілак». Кліндаміцин вводили 7 діб інтравагінально у об'ємі 50 мкл, які містили 0,043 г препарату на 1 г ваги миші. Період виведення препарату з організму становив 3 доби, після чого вводили «Вагілак» (Ядран, Хорватія): 5 діб 1 раз на добу в об'ємі 50 мкл суспензії з пробіотичного препарату, що містила $1 \times 10^{9}$ КУО/мл Lactobacillus spp. Контрольний висів проводили через 10 та 20 діб, відстежуючи динаміку змін;

«Біоспорин» (Біофарма, Україна) вводили інтравагінально: 5 діб - 1 раз на добу в об'ємі 50 мкл суспензії з пробіотичного препарату, що містила $1 \times 10^{9}$ КУО/мл Bacillus spp. (експериментальна група 2, n = 10). Паралельно здоровим тваринам експериментальної групи $1(\mathrm{n}=10)$ вводили пробіотик за тією ж схемою. Контроль - здорові тварини, яким інтравагінально вводили 50 мкл фізіологічного розчину;

- комплекс «Біоспорин» - «Вагілак»: 5 діб - 1 раз на добу вводили 50 мкл суспензії клітин 3 препарату «Біоспорин», що містила $1 \times 10^{9}$ КУО/мл Bacillus spp. Через 5 діб після завершення введення препарату тваринам починали вводити суспензію клітин 3 пробіотика «Вагілак»: 5 діб - 1 раз на добу в об'ємі 50 мкл, що містила $1 \times 10^{9}$ КУО/мл Lactobacillus spp. Зміни у мікробіоценозі відстежували протягом 40 діб від початку експерименту, виконуючи висіви через 10 та 20 діб після завершення введення препаратів. Дану комбінацію обрано через те, що Bacillus spp. 3 біоспорину відрізняються високою антагоністичною активністю, тобто можуть забезпечити елімінацію умовно-патогенних мікроорганізмів через реалізацію конкурентних відносин, а Lactobacillus spp. 3 препарату вагілак необхідні для реколонізації піхви сапрофітними мікроорганізмами.

Для порівняльного аналізу ефективності застосування різних схем корекції складу мікробіоти репродуктивного тракту використовували схеми:

- «Бактеріофаг стафілококовий рідкий» (Микроген, РФ) вводили інтравагінально по 50 мкл протягом 5 діб;

- пробіотичний препарат «Вагілак» (Ядран, Хорватія) вводили інтравагінально по 50 мкл протягом 5 діб у вигляді 50 мкл суспензії 3 пробіотичного препарату (отримана суспензія містила $1 \times 10^{9}$ клітин/мл бактерій);

- комплекс - «Бактеріофаг стафілококовий рідкий» - «Вагілак». Препарати вводили одночасно інтравагінально по 50 мкл протягом 5 діб.

Всі дослідження на тваринах проводилися відповідно норм, встановлених законом України №3447-IV «Про захист тварин від жорстокого поводження» та прийнятим у Європейській конвенції по захисту хребетних тварин, що використовуються для експериментальних цілей [6].

Статистичну обробку отриманих результатів проводили з використанням програм OriginLab Pro 7.0 та Microsoft Excel.

\section{Результати дослідження та їх обговорення}

Як показано у наших попередніх дослідженнях [4], при дисбактеріозі навіть на 30-ту добу після введення суспензії клітин стафілококів не відбувається спонтанного відновлення мікробіоти до стану норми, що не в останню чергу пов'язано із підтриманням кількості стафілококів та інших умовно-патогенних мікроорганізмів на значно більш високому рівні, порівняно 3 контролем. Тому значний інтерес у плані корекції дисбактеріозу представляє пошук засобів, які ефективно та специфічно знищують ці мікроорганізми, не шкодять сапрофітним бактеріям та сприяють відновленню їх вмісту. Для досліджень було використано різні комбінації біологічно активних препаратів, зокрема, комбінації препаратів антибіотиків, фагів та пробіотиків, що мало на меті вдосконалення терапевтичних схем [2,3].

Для корекції викликаного стану було застосовано різні схеми, які показали різну ефективність (рис. 1 і 2).

Визначено, що отримані при інтравагінальному введенні біоплівкотвірного штаму $S$. aureus зміни частоти виявлення маркерних мікроорганізмів були типові для дисбактеріозу [4]. Так, зростала частота виявлення умовно-патогенних мікроорганізмів та зменшувалася кількість сапрофітних бактерій.

Застосування різних схем корекції дозволило встановити, що найбільш ефективними серед них були 
комплексні, що включали послідовне використання двох різних препаратів пробіотиків поспіль.

Схема із застосування бактеріофагу стафілококового рідкого та вагілаку характеризувалася ефективною елімінацією стафілококів - частота виявлення $22,2 \%$ при показнику контроля - 100\%, та відновленням пулу лактобацил до 100\% виявлення у тварин. Водночас, порівняно 3 іншими схемами частота виявлення ентеробактерій не знижувалася до показників контрольної групи здорових тварин. У цьому сенсі більш ефективною показала себе схема із застосуванням двох пробіотиків Біоспорину та Вагілаку. У якості додаткового маркера введено мікроорганізми роду Bacillus, які є компонентом одного 3 препаратів, що мало на меті контроль їх самоелімінації. Визначено, що на завершальну добу експерименту частота їх виявлення практично сягала такої у контрольній групі. Канонічна ж схема з використанням кліндаміцину не сприяла елімінації стафілококу.

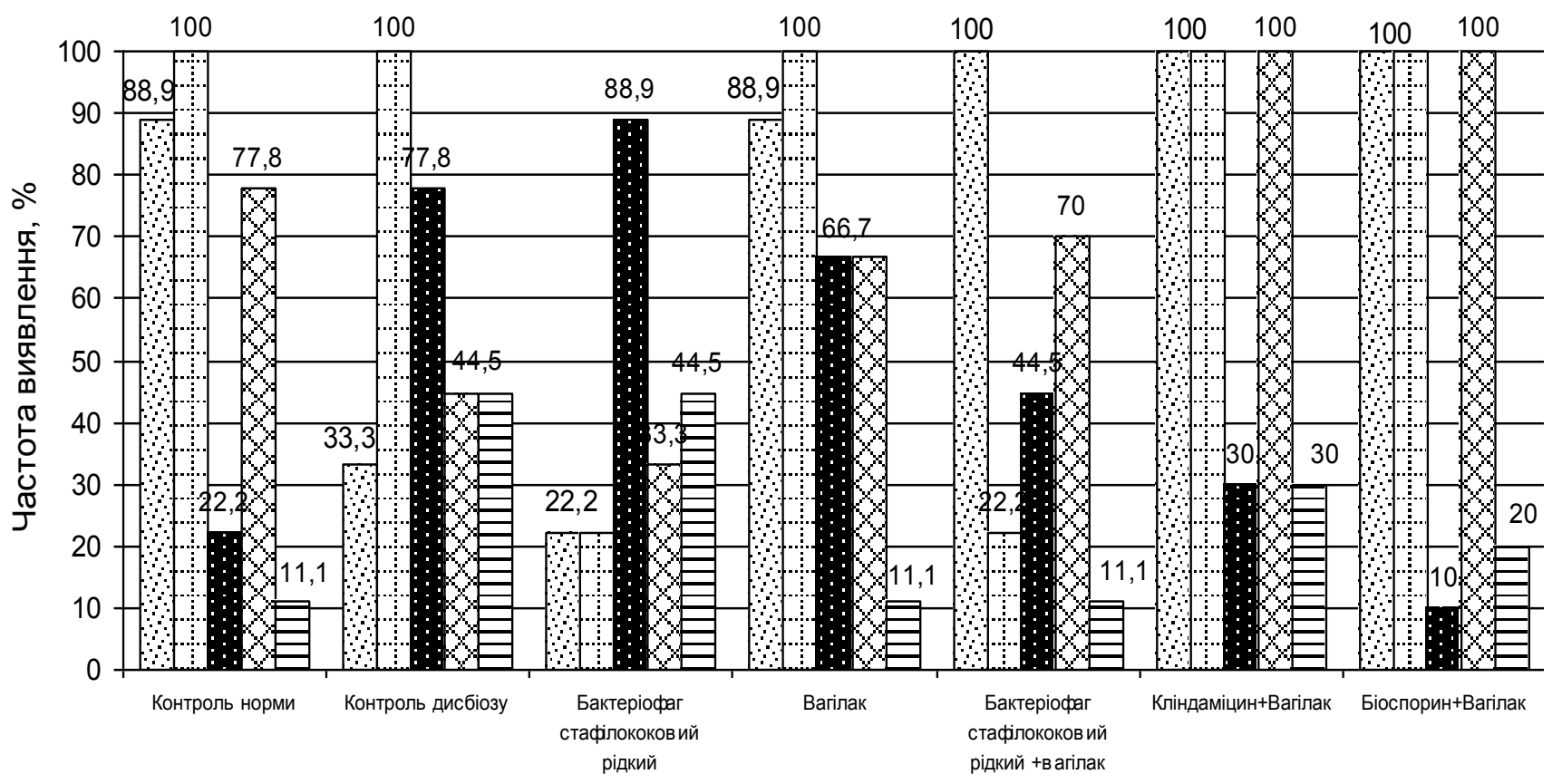

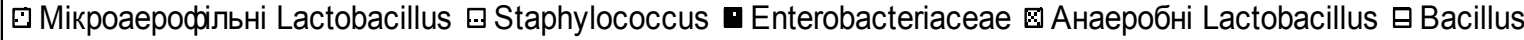

Рис. 1. Частота виявлення маркерних мікроорганізмів при застосуванні різних схем корекції дисбактеріозу на 20-ту добу після завершення введення препаратів

Окреме введення бактеріофагу стафілококового рідкого тваринам 3 дисбактеріозом піхви та окреме застосування вагілаку здійснювали значно менш виражений ефект. Головними відмінностями було те, що при окремому застосуванні фагового препарату відмічалося ефективне зниження стафілококового навантаження, практично без змін по інших маркерних мікроорганізмах, у той час як при застосуванні вагілаку спостерігалося лише відновлення лактобацилярного компоненту, а частота виявлення умовно-патогенних мікроорганізмів лишалася високою.

Аналіз змін кількісних показників маркерних мікроорганізмів дозволив встановити, що застосування всіх схем корекції здійснювало позитивний вплив на мікробіоту. Так, будь-яка 3 застосованих схем характеризувалася відновленням кількості лактобацил, що в усіх випадках ставала вищою за контрольний показник дисбактеріозу. Найбільш ефективне відновлення було зафіксовано для схем із застосуванням вагілаку, коли кількість лактобацил склала для комплексу зі

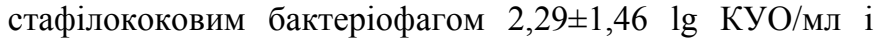
$2,24 \pm 1,08 \mathrm{lg}$ КУО/мл для комплексу 3 біоспорином, що фактично дорівнювало контролю норми.

Найбільш ефективне зниження кількості стафілококів - у 30 разів - мало місце при застосуванні схеми бактеріофаг стафілококовий та вагілак [3], хоча інші комплексні схеми також показували зниження у понад 17 разів, що можна пояснити наявністю серед діючих агентів у першому комплексі специфічного протистафілококового засобу.

Індекс відношення аероби: анаероби у розгорнотому дослідженні складу мікробіоти при застосуванні комплексних схем 3 бактеріофагами [3] становив від 1:59 до 1:67, що дозволяе стверджувати ефективність відновлення порівняно 3 контролем здорових тварин, для якого вказаний індекс становив 1:52. Вказаний індекс для схеми 3 двох пробіотиків становив 1:58, що також фактично відповідає нормі. Крім того, для цієї схеми відмічено найбільш ефективне відновлення вмісту мікроаерофільних лактобацил. 


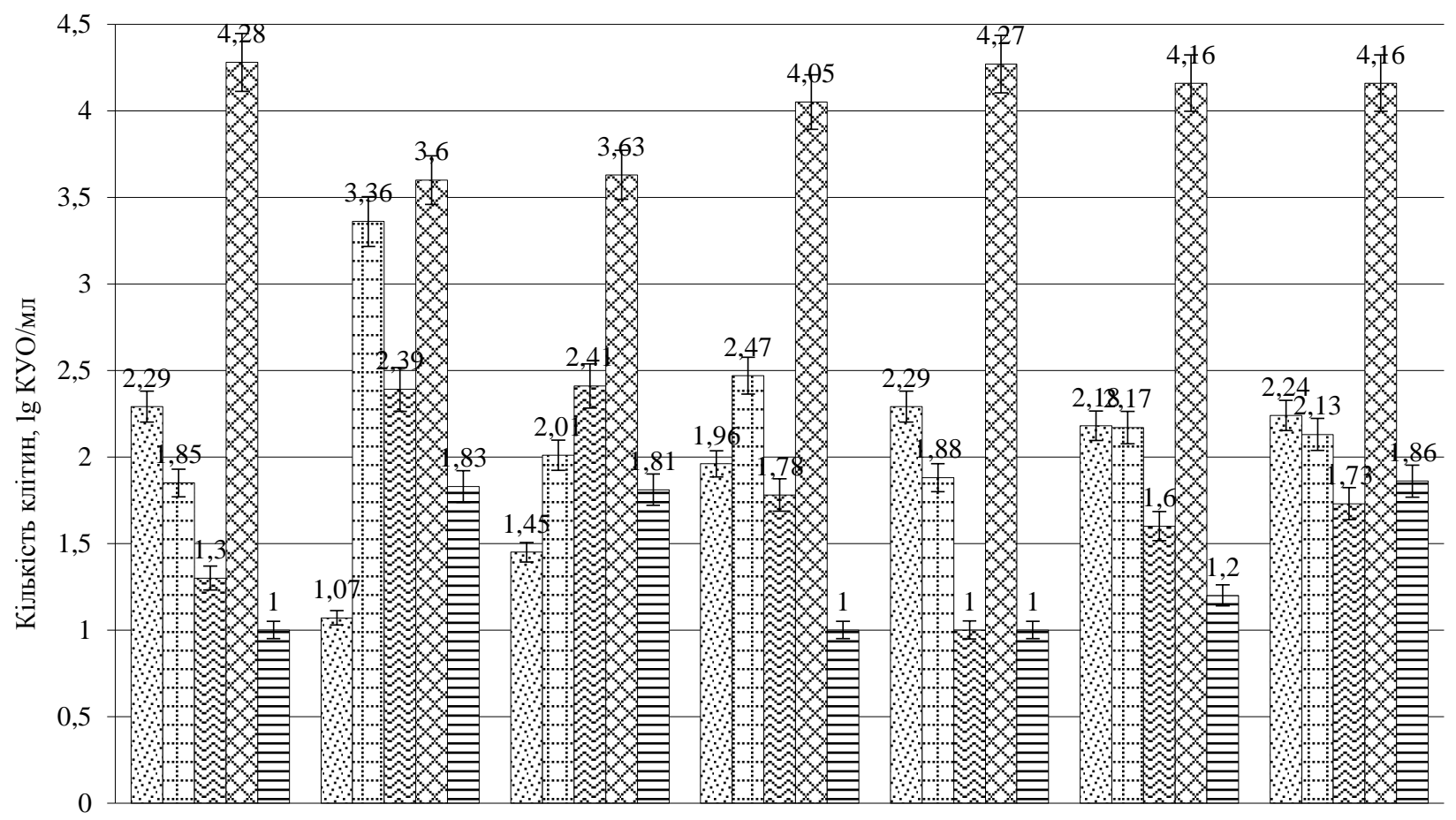

Контроль норми Контроль дисбіозу сагілак
Бактеріофаг стафілококовий рідкий
Бактеріофаг стафілококовий рідкий +вагілак
Кліндаміцин + Багілак
Біоспорин + Вагілак

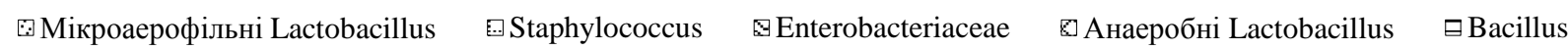

Рис. 2. Кількість маркерних мікроорганізмів при застосуванні різних схем корекції дисбактеріозу на 20-ту добу після завершення введення препаратів $(\mathrm{P}<0,05)$

Дослідження ефективності корекційних схем при відновленні складу мікробіоти піхви мишей у випадку дисбактеріозу, викликаного введенням біоплівкотвірного стійкого до антибіотиків пеніциліну, гентаміцину та офлоксацину штаму дозволило встановити, що всі схеми мали практично подібну ефективність, як і у випадку 3 біоплівкотвірним, але чутливим до антибіотиків штамом (рис. 3 і 4).

Як і у випадку з чутливим до антибіотиків штамом більшу ефективність мали комплексні корекційні схеми, серед яких схема «біоспорин - вагілак» показала найкращі результати: лактобацили було виявлено у всіх тварин і відмічено зниження частоти виявлення ентеробактерій до $10 \%$, що відповідає нормі. Власне самі бацили виявлені лише у 20\% тварин. Схема, що крім вагілаку включала стафілококовий бактеріофаг мала меншу ефективність щодо відновлення сапрофітних мікроорганізмів, однак, була значно більш ефективною проти стафілококів, які було виявлено у 30\% тварин. Окреме введення фагового препарату та вагілаку мали проміжний ефект [3].

Показники кількісних змін маркерних мікроорганізмів показали тенденції подібні до таких, що відмічені при дослідженні ефективності різних схем корекції дисбактеріозу, що викликаний введенням чутливого до антибіотиків штаму. Комплексні схеми показали найбільший ефект впливу. Так, на 20-ту добу після завершення введення препаратів відмічено позитивний результат, що проявлявся у відновленні кількості лактобацил до показника норми у випадку застосування комплексної схеми «біоспорин - вагілак» $2,25 \pm 1,08 \lg$ КУО/мл. Також подібний ефект показаний для схеми «стафілококовий бактеріофаг - вагілак» [3] та «кліндаміцин - вагілак».

Індекс відношення аероби: анаероби за загальним аналізом даних про склад мікробіоти тварин [2,3] також мав тенденцію до зростання. Так, при контрольному значенні 1:60 у групах тварин, для яких застосовували корекційні схеми, він становив від 1:53 до 1:58, що також свідчило на користь відновлення рівноваги у складі мікробіоценозу.

Терапія антибактеріальними препаратами призводить до дестабілізації вагінальної екосистеми, внаслідок чого відбувається різке зниження кількісних i якісних характеристик нормальної сінергідної мікробіоти, збільшення $\mathrm{pH}$ вагінального секрету, тобто створюються умови для масового розмноження умовно-патогенної мікробіоти [8]. Одним 3 домінуючих таксонів при дисбіотичних порушеннях мікробіоценозу репродуктивного тракту, у тому числі i опосередкованому застосуванням антибіотикотерапії [27], є бактерії виду $S$. aureus, що характеризуються здатністю до швидкої колонізації вагінального біотопу [33,34]. Використання 
двох пробіотиків поспіль є доволі ефективним засобом корекції дисбактеріозу, що найкраще підходить у випадках значних змін мікробіоти. При виражених змінах лише стафілококового компоненту мікробіоти доцільним буде розглянути можливість його ерадикації 3 використанням фагів.

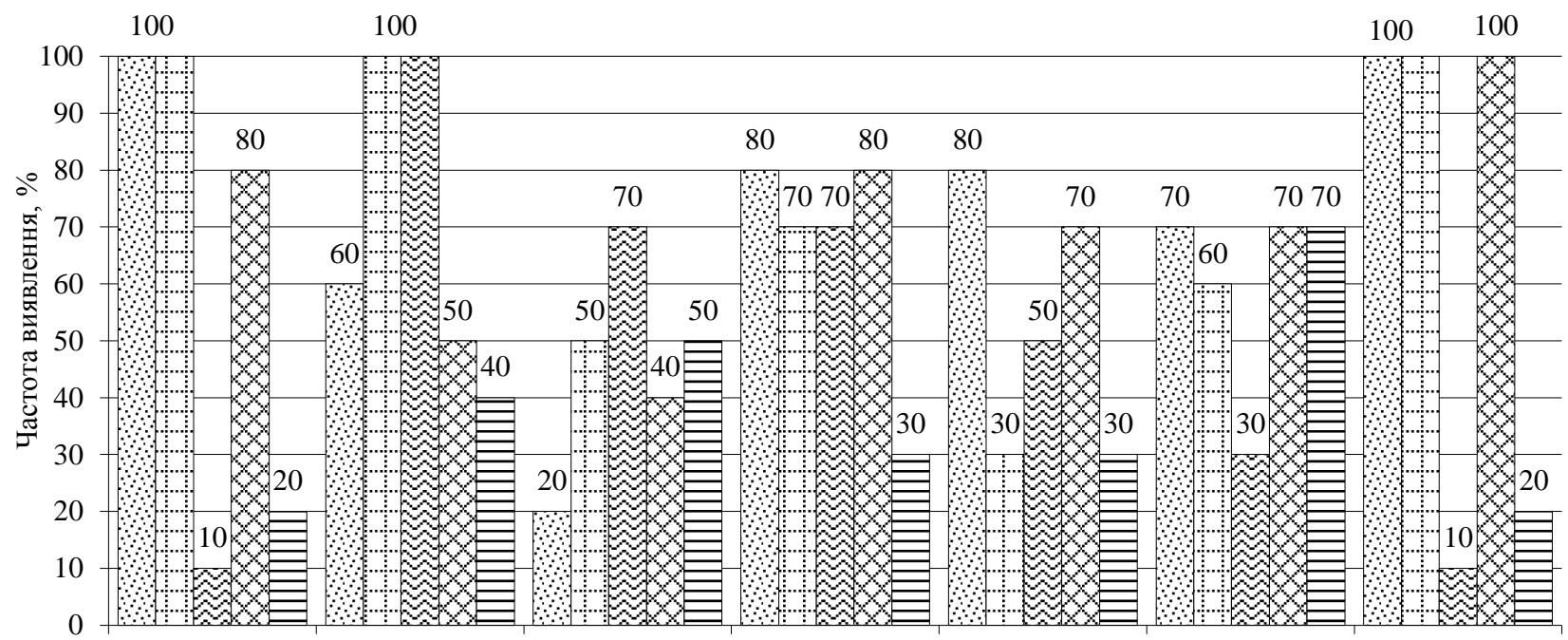

Контроль норми Контроль дисбіозу
Кагілак сілй рідкий

๑ Мікроаерофільні Lactobacillus $\square$ Staphylococcus $\quad$ Enterobacteriaceae $\square$ Анаеробні Lactobacillus $\boxminus$ Bacillus

Рис. 3. Частота виявлення маркерних мікроорганізмів при застосувані різних схем корекції дисбактеріозу на 20-ту добу після завершення введення препаратів

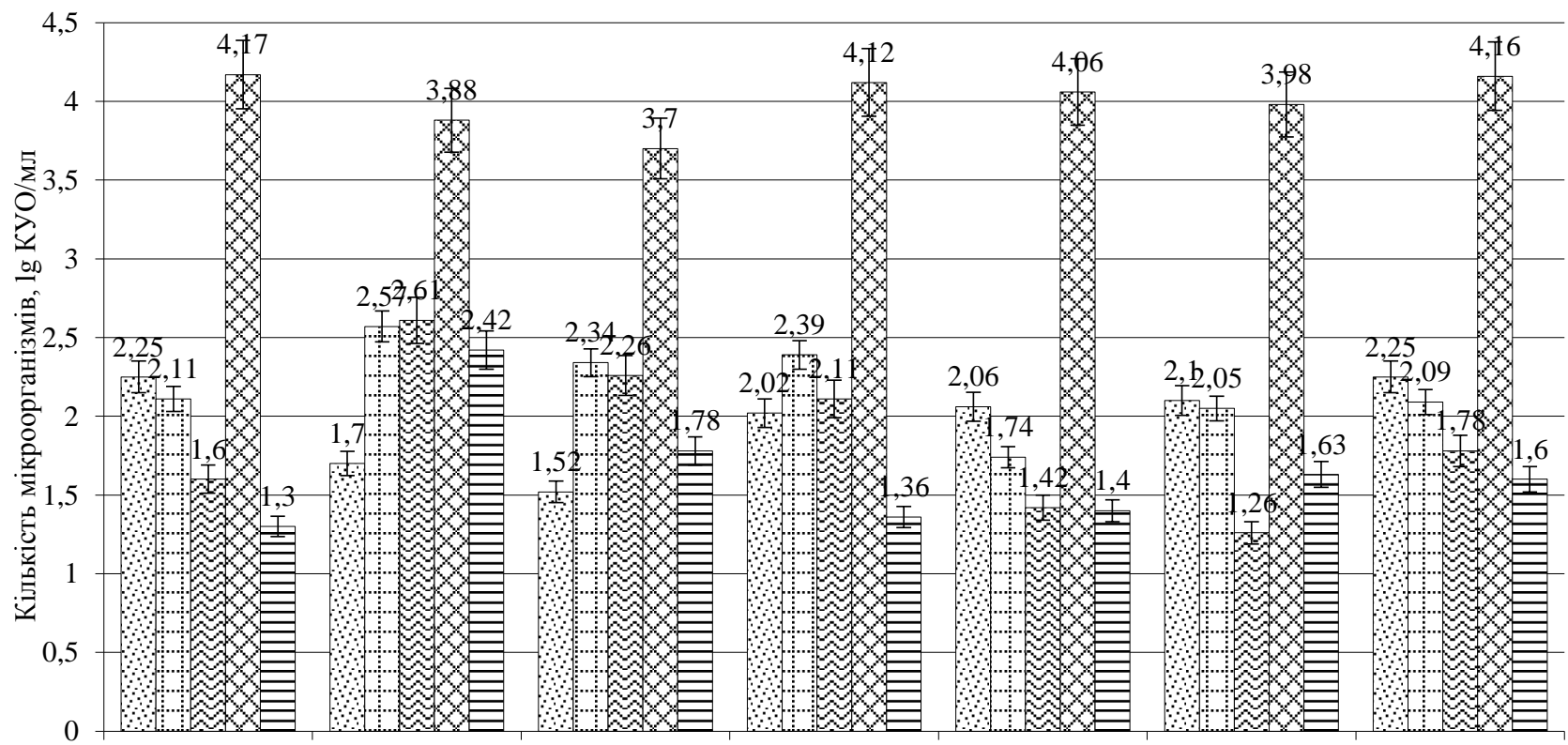

Контроль норми Дисбіоз
Бактеріофаг стафілококовий рідкий 
Препарати бактеріофагів вважаються одними 3 найбільш ефективних, адже здійснюють ефект у відношенні 78,3-93,6\% штамів, у тому числі і стійких до антибіотиків [13]. Водночас, окреме застосування фагів навряд чи вирішить проблему дисбактеріозу повністю, адже корекцію будь-яких порушень складу мікробіоти нижнього відділу статевих шляхів необхідно розглядати 3 позицій вчення про біоценози як складні полімікробіні системи. Крім того, слід пам'ятати, що виявлення патогенних мікроорганізмів у будь-якому разі повинно супроводжуватися антибіотикотерапією. Саме тому у лікуванні дісбіотичних порушень репродуктивного тракту важливий комплексний підхід, що включає наявність двох етапів [20] - після елімінації специфічного збудника необхідне відновлення біоценозу піхви. Тільки такий інтегрований підхід забезпечує ефективність лікування і запобігає рецидивам запального процесу [12], а також сприяє відновленню нормальної мікробіоти піхви [17].

Для закріплення позитивних змін другим етапом корекції має бути застосування пробіотичного препарату, що сприятиме відновленню мікроекології піхви [14].

Тенденції змін складу мікробіоти, встановлені у розробленій нами моделі відповідають таким, що показані для застосування стандартних протокольних схем [15], що дозволяє рекомендувати отримані щодо корекційного впливу на мікробіоту дані до розгляду як перспективні заходи іiі відновлення у випадку розвитку дисбіозів, зумовлених біоплівкотвірними штамами умовнопатогенних бактерій [11].

\section{Висновки}

Порівнюючи отримані щодо корекції дисбактеріозів результати, можна зазначити, що найбільш ефективними були комплексні схеми «бактеріофаг пробіотик» та «пробіотик - пробіотик», що у випадку дисбактеріозу, створеного шляхом інтравагінального введення біоплівкотвірного штаму S. aureus 48, сприяли відновленню мікробіоти піхви до складу норми. Ефективними комбінаціями виявилися такі, що включали «Бактеріофаг стафілококовий рідкий» та «Біоспорин» поряд 3 пробіотиком «Вагілак», що може бути пояснено особливостями їх складу. І ця схема може бути розглянута як комплексний терапевтичний захід. Остаточний вибір схеми також повинен грунтуватися на дослідженні індивідуальних особливостей біологічних властивостей представників мікробіоти, що дозволить передбачати, яка саме схема буде найбільш ефективною у кожному конкретному випадку.

\section{Література}

1. Балко ОБ, Авдєєва ЛВ. Структурні компоненти і особливості організації біоплівки Pseudomonas aeruginosa. Мікробіологічний журнал. 2010; 72(4): 28-33.

2. Вальчук СІ, Шевченко ТМ, Шевченко ВА, Воронкова ОС, Вінніков АІ. Корекція дисбактеріозу піхви 3 використанням пробіотиків. Вісник Дніпропетровського університету. Серія Біологія, медицина. 2015 ; 6 (1): 74-78.

3. Воробєй ЄC, Воронкова ОС, Вінніков АI. Корекція дисбактеріозу піхви мишей, викликаного біоплівкотвірним штамом Staphylococcus aureus, за допомогою бактеріофагів і пробіотиків. Regulatory Mechanisms in Biosystems. 2017; 8 (2): 252-258.

4. Воронкова ОС, Сирокваша ЕА, Винников АИ. Модель экспериментального вагинального дисбиоза на белых лабораторных мышах. Мікробіологічний журнал. 2008; 6: 47-58.

5. Дяченко ВФ, Бірюкова СВ, Старобінець ЗГ, Калініченко МФ, Флегонтова ВВ, Гайдаш IC, Москаленко ВФ, Романюк БП, Марющенко АМ, Давидова СМ, Гречко ВА, Чернявський ВI, Альсабан А, Дзюбан НФ, Дзюба АI, Волянський АЮ, Пащенко НВ, Волянська НП, Тарасов ОА, Джурович Р, Клиса ТЛ, Суглобов СВ, Шевченко МЮ, Пількевич НБ. Лабораторна діагностика гнійно-запальних захворювань, обумовлених аспорогенними анаеробними мікроорганізмами. Методичні рекомендації МОЗ України. Харків; 2000.

6. Свропейська конвенція про захист хребетних тварин, що використовуються для дослідних та інших наукових цілей / Страсбург, 18 березня 1986 року: збірка договорів Ради Свропи: українська версія. За ред. Вишневського ЄМ. Київ: Парламентське видавництво; 2000.

7. Западнюк ИП, Западнюк ВИ, Захария ЕА, Западнюк БВ. Лабораторные животные. Разведение, содержание, использование в эксперименте. Киев: Вища школа; 1983.

8. Кононова ИН, Смирнова ЕГ. Пробиотическая терапия для коррекции микробиоценоза репродуктивного тракта перед родами. Проблемы репродукции. 2008; 4: 91-94.

9. Краткий определитель бактерий Берги. Под ред. Хоулта Дж. М: Мир; 1980.

10. Лаврик ГС, Корнійчук ОП. Біоплівкова форма стафілококів у моно- та бівидовій культурі в поєднанні 3 лактобацилами. Biol. Stud. 2015; 9(3-4): 89-98.

11. Маланчук ЛМ, Маланчук СЛ, Небесьо ТА. Вагінальна мікробіота: як відновити баланс при дисбактеріозі. Здоровье женщины. 2016; 2 (108): 107-111.

12. Менухова Ю.Н. Сравнительная оценка клинических и микробиологических методов диагностики и эффективности лечения бактериального вагиноза. Дис. канд. мед. наук. Санкт-Петербург: НИИАГ имени Д.О. Отта СЗО PAMH; 2014: 148. 
13. Мотовилова ТМ, Качалина ТС, Аникина ТА. Оценка роли бактериофагов в этиотропной терапии инфекционно-воспалительных процессов на примере лечения хронического неспецифического эндометрита. Взгляд клинициста. Трудный пациент. 2013; 11 (8-9): 20-24.

14. Нагорная ВФ. Рациональный выбор пробиотиков для комплексной терапии вагинальных инфекций. Здоровье женщины. 2010; 9 (55): 149-154.

15. Назаренко ЛГ, Соловьева НП. Применение орального пробиотика как альтернативная клиническая стратегия профилактики акушерских и перинатальных инфекций. Український журнал дерматології, венерології, косметології. 2013; 4 (51): 147-154.

16. Об унификации микробиологических (бактериологических) методов исследования, применяемых в клинико-диагностических лабораториях лечебно-профилактических учреждений: приказ № 535 от 22.04 .1985 г. Москва: МОЗ СССР, 1985.

17. Ордиянц ИМ, Четвертакова ЭС, Чымба АА, Клычмамедова ГБ. Бактериальный вагиноз: диагностика и лечение на современном этапе. Земский врач. 2011; 2: 28-30.

18. Про затвердження клінічних протоколів з акушерської та гінекологічної допомоги: наказ № 582 від 15.12.2003 р. Київ: Міністерство охорони здоров’я України; 2003.

19. Про затвердження методичних вказівок «Визначення чутливості мікроорганізмів до антибактеріальних препаратів»: наказ Міністерства охорони здоров’я України № 167 від 05.04.2007 р. Київ: МОЗ України; 2007.

20. Радзинский ВЕ, Ордиянц ИМ. Двухэтапная терапия вагинальных инфекций. Москва: StatusPraesens; 2012.

21. Собкова ЖВ, Філоненко ГВ, Сурмашева ОВ, Росада МО. Вивчення видового складу мікроорганізмів в біоплівках на судинних та сечових катетерах у багатопрофільному стаціонарі. Scientific Journal ScienceRise: Biological Science. 2017; 2(5): 38-42.

22. Янковский ДС, Дымент ГС. Использование пробиотиков с целью улучшения репродуктивного здоровья женщины. Здоровье женщины. 2008; 2: 161-170.

23. Becker K, Heilmann C, Peters G. Coagulase-negative staphylococci. Clin Microbiol Rev. 2014; 27: 870-926.

24. Bester E, Kroukamp O, Hausner M, Edwards EA, Wolfaardt GM. Biofilm form and function: carbon availability affects biofilm architecture, metabolic activity and planktonic cell yield. Journal of Applied Microbiology. 2010; 110: 387-398.

25. Chen L, Wen YM. The role of bacterial biofilm in persistent infections and control strategies. Int J Oral Sci. 2011; 3 (2): 66-73.

26. Kiedrowski MR, Horswill AR. New approaches for treating staphylococcal biofilm infections. Ann N Y Acad Sci. 2011; 1241: 104-121.

27. Klatt TE, Cole DC, Eastwood DC, Barnabei VM. Factors associated with recurrent bacterial vaginosis. The Journal Reproductive Medicine. 2010; 55 (1-2): 55-61.

28. Kutateladze M, Adamia R. Bacteriophages as potential new therapeutics to replace or supplement antibiotics. Trends in Biotechnology. 2010; 28 (12): 591-595.

29. Lebeaux D, Chauhan A, Rendueles O, Beloin C. From in vitro to in vivo models of bacterial biofilm-related infections. Pathogens. 2013; 2: 288-356.

30. Lowy FD. Staphylococcus aureus infections. N Engl J Med. 1998; 339: 520-532.

31. Paharik AE, Horswill AR. The Staphylococcal Biofilm: Adhesins, regulation, and host response. Microbiol Spectr. 2016; 4 (2): 1-48.

32. Sievert DM, Ricks P, Edwards JR, Schneider A, Patel J, Srinivasan A, Kallen A, Limbago B, Fridkin S. Antimicrobial-resistant pathogens associated with healthcare-associated infections: summary of data reported to the National Healthcare Safety Network at the Centers for Disease Control and Prevention, 2009-2010. Infection control and hospital epidemiology. 2013; 34: 1-14.

33. Swidsinski A, Verstraelen H, Loening-Baucke V, Swidsinski S, Mendling W, Halwani Z. Presence of a polymicrobial endometrial biofilm in patients with bacterial vaginosis. PLoS One. 2013; 8 (1): 1-5.

34. Verstraelen H, Swidsinski A. The biofilm in bacterial vaginosis: implications for epidemiology, diagnosis and treatment. Current Opinion in Infectious Diseases. 2013; 26 (1): 86-89.

\section{References}

1. Balko, O.B, Avdieieva, L.V. Strukturni komponenty i osoblyvosti orhanizatsii bioplivky Pseudomonas aeruginosa. Mikrobiolohichnyi zhurnal. 2010; 72(4): 28-33.

2. Valchuk, S.I, Shevchenko, T.M, Shevchenko, V.A, Voronkova, O.S, Vinnikov, A.I. Korektsiia dysbakteriozu pikhvy z vykorystanniam probiotykiv. Visnyk Dnipropetrovskoho universytetu. Seriia Biolohiia, medytsyna. 2015; 6 (1): 74-78.

3. Vorobiei, Ye.S, Voronkova, O.S, Vinnikov, A.I. Korektsiia dysbakteriozu pikhvy myshei, vyklykanoho bioplivkotvirnym shtamom Staphylococcus aureus, za dopomohoiu bakteriofahiv i probiotykiv. Regulatory Mechanisms in Biosystems. 2017; 8 (2): 252-258. 
4. Voronkova, O.S, Syrokvasha, E.A, Vynnykov, A.Y. Model eksperimentalnogo vaginalnogo disbioza na belyh laboratornyh myshah. Mikrobiolohichnyi zhurnal. 2008; 6: 47-58.

5. Diachenko, V.F, Biriukova, S.V, Starobinets, Z.H, Kalinichenko, M.F, Flehontova, V.V, Haidash, I.S, Moskalenko, V.F, Romaniuk, B.P, Mariushchenko, A.M, Davydova, S.M, Hrechko, V.A, Cherniavskyi, V.I, Alsaban, A, Dziuban, N.F, Dziuba, A.I, Volianskyi, A.Iu, Pashchenko, N.V, Volianska, N.P, Tarasov, O.A, Dzhurovych, R, Klysa, T.L, Suhlobov, Ye.V, Shevchenko, M.Iu, Pilkevych, N.B. Laboratorna diahnostyka hniino-zapalnykh zakhvoriuvan, obumovlenykh asporohennymy anaerobnymy mikroorhanizmamy. Metodychni rekomendatsii MOZ Ukrainy. Kharkiv; 2000.

6. Ievropeiska konventsiia pro zakhyst khrebetnykh tvaryn, shcho vykorystovuiutsia dlia doslidnykh ta inshykh naukovykh tsilei / Strasburh, 18 bereznia 1986 roku: zbirka dohovoriv Rady Yevropy: ukrainska versiia. Za red. Vyshnevskoho, Ye.M. Kyiv: Parlamentske vydavnytstvo; 2000.

7. Zapadnyuk, I.P, Zapadnyuk, V.I, Zahariya,. EA, Zapadnyuk, B.V. Laboratornye zhivotnye. Razvedenie, soderzhanie, ispolzovanie v eksperimente. Kiev: Visha shkola; 1983.

8. Kononova, I.N, Smirnova, E.G. Probioticheskaya terapiya dlya korrekcii mikrobiocenoza reproduktivnogo trakta pered rodami. Problemy reprodukcii. 2008; 4: 91-94.

9. Kratkij opredelitel bakterij Bergi. Pod red. Houlta Dzh. M: Mir; 1980.

10. Lavryk, H.S, Korniichuk, O.P. Bioplivkova forma stafilokokiv u mono- ta bivydovii kulturi v poiednanni $\mathrm{z}$ laktobatsylamy. Biol. Stud. 2015; 9(3-4): 89-98.

11. Malanchuk, L.M, Malanchuk, S.L, Nebeso, T.A. Vahinalna mikrobiota: yak vidnovyty balans pry dysbakteriozi. Zdorove zhenshchynы. 2016; 2 (108): 107-111.

12. Menuhova, Yu.N. Sravnitelnaya ocenka klinicheskih i mikrobiologicheskih metodov diagnostiki i effektivnosti lecheniya bakterialnogo vaginoza. Dis. kand. med. nauk. Sankt-Peterburg: NIIAG imeni D.O. Otta SZO RAMN; 2014 : 148.

13. Motovilova, T.M, Kachalina, T.S, Anikina, T.A. Ocenka roli bakteriofagov v etiotropnoj terapii infekcionnovospalitelnyh processov na primere lecheniya hronicheskogo nespecificheskogo endometrita. Vzglyad klinicista. Trudnyj pacient. 2013; 11 (8-9): 20-24.

14. Nagornaya, V.F. Racionalnyj vybor probiotikov dlya kompleksnoj terapii vaginalnyh infekcij. Zdorove zhenshiny. 2010; 9 (55): 149-154.

15. Nazarenko, L.G, Soloveva, N.P. Primenenie oralnogo probiotika kak alternativnaya klinicheskaya strategiya profilaktiki akusherskih i perinatalnyh infekcij. Ukrayinskij zhurnal dermatologiyi, venerologiyi, kosmetologiyi. 2013; 4 (51): $147-154$.

16. Ob unifikacii mikrobiologicheskih (bakteriologicheskih) metodov issledovaniya, primenyaemyh $\mathrm{v}$ klinikodiagnosticheskih laboratoriyah lechebno-profilakticheskih uchrezhdenij: prikaz № 535 ot 22.04.1985 g. Moskva: MOZ SSSR, 1985 .

17. Ordiyanc, I.M, Chetvertakova, E.S, Chymba, A.A, Klychmamedova, G.B. Bakterialnyj vaginoz: diagnostika i lechenie na sovremennom etape. Zemskij vrach. 2011; 2: 28-30.

18. Pro zatverdzhennia klinichnykh protokoliv z akusherskoi ta hinekolohichnoi dopomohy: nakaz № 582 vid 15.12.2003 r. Kyiv: Ministerstvo okhorony zdorovia Ukrainy; 2003.

19. Pro zatverdzhennia metodychnykh vkazivok «Vyznachennia chutlyvosti mikroorhanizmiv do antybakterialnykh preparativ»: nakaz Ministerstva okhorony zdorovia Ukrainy № 167 vid 05.04.2007 r. Kyiv: MOZ Ukrainy; 2007.

20. Radzinskij, V.E, Ordiyanc, I.M. Dvuhetapnaya terapiya vaginalnyh infekcij. Moskva: StatusPraesens; 2012.

21. Sobkova, Zh.V, Filonenko, G.V, Surmasheva, O.V, Rosada, M.O. Vivchennya vidovogo skladu mikroorganizmiv v bioplivkah na sudinnih ta sechovih kateterah u bagatoprofilnomu stacionari. Scientific Journal ScienceRise: Biological Science. 2017; 2(5): 38-42.

22. Yankovskij, D.S, Dyment, G.S. Ispolzovanie probiotikov s celyu uluchsheniya reproduktivnogo zdorovya zhenshiny. Zdorove zhenshiny. 2008; 2: 161-170.

23. Becker K, Heilmann C, Peters G. Coagulase-negative staphylococci. Clin Microbiol Rev. 2014; 27: 870-926.

24. Bester E, Kroukamp O, Hausner M, Edwards EA, Wolfaardt GM. Biofilm form and function: carbon availability affects biofilm architecture, metabolic activity and planktonic cell yield. Journal of Applied Microbiology. 2010; 110: 387-398.

25. Chen L, Wen YM. The role of bacterial biofilm in persistent infections and control strategies. Int J Oral Sci. 2011; 3 (2): $66-73$.

26. Kiedrowski MR, Horswill AR. New approaches for treating staphylococcal biofilm infections. Ann N Y Acad Sci. 2011; 1241: 104-121.

27. Klatt TE, Cole DC, Eastwood DC, Barnabei VM. Factors associated with recurrent bacterial vaginosis. The Journal Reproductive Medicine. 2010; 55 (1-2): 55-61.

28. Kutateladze M, Adamia R. Bacteriophages as potential new therapeutics to replace or supplement antibiotics. Trends in Biotechnology. 2010; 28 (12): 591-595.

29. Lebeaux D, Chauhan A, Rendueles O, Beloin C. From in vitro to in vivo models of bacterial biofilm-related infections. Pathogens. 2013; 2: 288-356.

30. Lowy FD. Staphylococcus aureus infections. N Engl J Med. 1998; 339: 520-532. 
31. Paharik AE, Horswill AR. The Staphylococcal Biofilm: Adhesins, regulation, and host response. Microbiol Spectr. 2016; 4 (2): 1-48.

32. Sievert DM, Ricks P, Edwards JR, Schneider A, Patel J, Srinivasan A, Kallen A, Limbago B, Fridkin S. Antimicrobial-resistant pathogens associated with healthcare-associated infections: summary of data reported to the National Healthcare Safety Network at the Centers for Disease Control and Prevention, 2009-2010. Infection control and hospital epidemiology. 2013; 34: 1-14.

33. Swidsinski A, Verstraelen H, Loening-Baucke V, Swidsinski S, Mendling W, Halwani Z. Presence of a polymicrobial endometrial biofilm in patients with bacterial vaginosis. PLoS One. $2013 ; 8$ (1): 1-5.

34. Verstraelen H, Swidsinski A. The biofilm in bacterial vaginosis: implications for epidemiology, diagnosis and treatment. Current Opinion in Infectious Diseases. 2013; 26 (1): 86-89.

Дата надходження рукопису до редакції: 14.06.2019 p.

Порушення складу мікробіоти різних біотопів організму людини, знані як дисбіоз, є одними 3 найбільш поширених. Зміна складу мікробіоти може мати різні наслідки, у тому числі й опосередковано впливати на виникнення та розвиток інших типів патологічних процесів. Для запобігання розвитку ускладнень необхідним засобом $\epsilon$ корекція мікробіоти, що може бути здійснено з застосуванням різних засобів. Метою роботи було проаналізувати ефективність різних схем корекції експериментального дисбіозу репродуктивного тракту, змодельованого шляхом інтравагінального введення біоплівкотвірного штама $S$. aureus 46. Для досягнення мети було використано модель дисбіозу репродуктивного тракту на лабораторних тваринах, що отримана шляхом інтравагінального введення суспензії клітини біоплівкотвірного штама $S$. aureus 46. Виділення та ідентифікацію мікроорганізмів проводили 3 використанням стандартних бактеріологічних методів. Визначення стану мікробіоти здійснювали відповідно до лабораторних критеріїв. Визначено, що найбільш ефективними схемами відновлення мікробіоти репродуктивного тракту були комплексні, які включали «бактеріофаг стафілококовий рідкий - вагілак» та «біоспорин - вагілак», що у випадку дисбактеріозу, викликаного біоплівкотвірним штамом S. aureus 48, сприяли відновленню мікробіоти піхви до складу норми, що виражалося у зменшенні частоти виявлення та кількості стафілококів, ентеробактерій та зростанні індекса відношення аероби: анаероби, а також у збільшенні кількості лактобацил. Найбільш ефективною виявилася схема, що включає два пробіотики, яка може бути розглянута як комплексний терапевтичний захід.

Ключові слова: дисбіоз, репродуктивний тракт, мікробіота, відновлення, пробіотики, бактеріофаги.

Нарушение состава микробиоты различных биотопов организма человека, известные как дисбиоз, являются одними из наиболее распространенных. Изменение состава микробиоты может иметь различные последствия, в том числе и опосредованно влиять на возникновение и развитие других типов патологических процессов. Для предотвращения развития осложнений необходимой является коррекция микробиоты, что может быть осуществлено с применением различных средств. Целью работы было проанализировать эффективность различных схем коррекции экспериментального дисбиоза репродуктивного тракта, смоделированного путем интравагинального введения биопленкообразующего штамма $S$. aureus 46. Для достижения цели использовали модель дисбиоза репродуктивного тракта на лабораторных животных, полученную путем интравагинального введения суспензии клеток биопленкообразующего штамма $S$. aureus 46. Выделение и идентификацию микроорганизмов проводили с использованием стандартных бактериологических методов. Определение состояния микробиоты проводили в соответствии с лабораторными критериями. Установлено, что наиболее эффективными схемами восстановления микробиоты репродуктивного тракта были комплексные, включавшие «бактериофаг стафилококковый жидкий вагилак» и «биоспорин - вагилак», которые в случае дисбактериоза, вызванного биопленкообразующим штаммом S. aureus 4в, способствовали восстановлению микробиоты влагалища до состояния нормы, что выражалось в уменьшении частоты выявления и количества стафилококков, энтеробактерий и возрастании индекса отношения аэробы: анаэробы, а также в увеличении количества лактобацилл. Наиболее эффективным оказалось введение двух пробиотиков, что может быть рассмотрено как комплексная терапевтическая схема.

Ключевые слова: дисбиоз, репродуктивный тракт, микробиота, восстановление, пробиотики, бактериофаги.

Disorders of the microbiota of different biotopes of human body, known as dysbiosis, are the most common lesions. Changing the composition of microbiota can have different consequences, including indirectly affection on the emergence and development of other types of pathological processes. For prevention of the lesions, a necessary remedy is the correction of the microbiota, which can be carried out using various means. The aim of the research was to analyze the effectiveness of different correction schemes of experimental dysbiosis of the reproductive tract, modeled by intravaginal introduction of biofilm forming strain S. aureus 46. The model of reproductive tract dysbiosis in laboratory animals, obtained by intravaginal injection of a cell suspension of the biofilm forming strain of $S$. aureus 46 , was used to achieve this goal. Isolation and identification of microorganisms was done using standard bacteriological methods. Status of the microbiota was determined according to laboratory criteria. It was determined that the most effective schemes for correction of the microbiota of the reproductive tract 
were complex, which included "staphylococcal bacteriophage liquid - vahilak" and "biosporine - vahilak", which in the case of dysbacteriosis caused by biofilm forming strain $S$. aureus 46 , stimulated recovery which characterized by decrease of the detection rate and the number of staphylococci, enterobacteria, and by increase of the index of ratio aerobic to anaerobic bacteria, as well as an increase of frequency of isolation and amount of lactobacilli. The most effective was the scheme, which includes two probiotics, which can be considered as a comprehensive therapeutic measure.

Key words: dysbiosis, reproductive tract, microbiota, correction, probiotics, bacteriophages.

Конфлікт інтересів: відсутній.

Conflicts of interest: authors have no conflicts of interest to declare.

\section{Відомості про авторів}

Воронкова Ольга Сергіївна - д-р біол. наук, доцент, доцент кафедри загальної медицини 3 курсом фізичної терапії факультету медичних технологій діагностики та реабілітації Дніпровського національного університету імені Олеся Гончара; 49005 просп. Дмитра Яворницького, 35, м. Дніпро, Україна.

+380 (96) 225-04-63, voronkova.olga.04@gmail.com, Scopus ID 57088340700, ORCID 0000-0003-3380-6871.

Вінніков Альберт Іванович - д-р біол. наук, професор, професор кафедри загальної медицини 3 курсом фізичної терапії факультету медичних технологій діагностики та реабілітації Дніпровського національного університету імені Олеся Гончара; 49005 просп. Дмитра Яворницького, 35, м. Дніпро, Україна.

+380 (67) 790-70-92, a_vinnikov@ukr.net, Scopus ID 7003964363, ORCID 0000-0003-0893-7570.

Щербиніна Марина Борисівна - д-р мед. наук, професор, декан факультету медичних технологій діагностики та реабілітації, професор кафедри загальної медицини з курсом фізичної терапії факультету медичних технологій діагностики та реабілітації Дніпровського національного університету імені Олеся Гончара; 49005 просп. Дмитра Яворницького, 35, м. Дніпро, Україна.

+380 (67) 780-42-31, scherbinina@ua.fm, Scopus ID 6506181082, ORCID 0000-0001-6635-9743.

Дикленко Тетяна Вікторівна - старший викладач кафедри загальної медицини з курсом фізичної терапії факультету медичних технологій діагностики та реабілітації Дніпровського національного університету імені Олеся Гончара; 49005 просп. Дмитра Яворницького, 35, м. Дніпро, Україна.

+380 (67) 707-35-83, tdiklenko@gmail.com.

Примітка. У статтях збережено орфографію, пунктуацію та стилістику авторів. 